\title{
The Role of Teachers in Enhancing Information and Communication Technology-Integrated Education in Cambodia*
}

\section{SINETH SENG ${ }^{* *} \cdot$ HyEJEONG CHOI ${ }^{* *}$ AND HYUN S. SHIN ${ }^{* * *}$}

\begin{abstract}
The integration of ICT in education can be an effective method of improving the quality of education in developing countries. This paper aims to examine the role that teachers play in enhancing ICT-integrated education by analyzing the perception, belief and behavior of secondary school teachers in Cambodia $(\mathrm{N}=121)$. Its findings suggest that although the teachers have positive perception and belief towards ICTintegrated education, their usage of ICT in the classroom is notably limited. A number of barriers are identified such as inadequate ICT-related infrastructure and insufficient teacher training programs. Interestingly, ANOVA analysis reveals that female teachers have lower self-confidence with respect to ICT skills than do male teachers $(\mathrm{p}<.05)$. Policy implications regarding budget allocation and international public-private partnership are discussed.
\end{abstract}

Keywords: ICT, Secondary Education, Gender, Cambodia, Public-Private Partnership

* This paper was written based on the first author's Masters' Thesis. The third and corresponding author acknowledges financial support from the Ewha Womans University Research Grant of 2013 and Ewha Global Top 5 Grant of 2013.

** Ewha Womans University, Seoul, South Korea;

${ }^{* * *}$ Corresponding author, Assistant professor, Ewha Womans University, Seoul, South Korea; E-mail: hyun.shin@ewha.ac.kr; DOI: 10.16934/isr.15.2.201412.71 


\section{INTRODUCTION}

Education is regarded as a fundamental human right and a key driver of sustainable economic development (UNESCO 2004). Accordingly, the importance of education systems in developing countries has been emphasized (Wagner 2010). As a developing country, Cambodia has one of the youngest populations in the world (UNESCO 2010). Historically, Cambodia experienced a destructive civil war in the 1970s. About two decades later the country began to rebuild its education system through teacher training, curriculum revision, and massive distribution of textbooks. The Ministry of Education, Youth and Sport (MoEYS) has been at the center of such systematic reform of the Cambodian education system. According to Education Strategic Plan (ESP) 2006-2010, a report by MoEYS (2006), the Cambodian government has set priorities such as ensuring equitable access to education and increasing the quality of education services. Even though the goal of equitable access to education has been achieved, at least in urban areas, improvement in overall educational quality has been slow, particularly at the secondary school level (Engel 2010; Symaco and Brock 2013). For achieving sustainable development of Cambodia, however, improving the quality of secondary education is indispensable as the dropout rate remains high and the students' competency is still limited (VSO 2010).

One way to address this issue is to take advantage of information and communication technology (ICT) in education. It is widely acknowledged that ICT, as a powerful tool for disseminating information and knowledge, facilitates equitable access to education (Khan, Hasan and Clement 2012; Voogt and Gerald 2008). Moreover, ICT-integrated education is known to improve the quality of education through learning by doing, real time conversation, delayed time conversation and directed instruction (Ehrmann 1994). It also can help teachers move toward student-centered teaching and interactive learning, which can be particularly helpful within the domain of secondary education (MoEYS 2004). Given that the dropout rate in secondary schools remains high in Cambodia, the need is to provide students with more relevant curricula that will lead them to employment opportunities (UNESCO 2010). In this regard, ICT-integrated education would be useful by brining greater value and relevance to secondary school education.

Being aware of the importance of ICT for better education, MoEYS has actively promoted the use of ICT in education, working closely with such developping partners as UNESCO and the Open Institute (MoEYS 2004; UNESCO 2003; UNESCO 2010). In 2008, "ICT in Education Master Plan 2009-2013” was publicshed as a way of underscoring the ability of ICT to accomplish the following: 1) increase access to formal and informal basic/tertiary education and life-long learning even in rural areas; 2) improve the relevance and effectiveness of education by enhancing the quality of teaching and learning; and 3) develop those ICT-related skills that will benefit future employment. Subsequently, ICT in education has 
been emphasized in diverse settings according to Education Strategic Plan (ESP) 2009-2013 by MoEYS. At the secondary level, for example, all schools with computers were asked to train $90 \%$ of their upper secondary school teachers in ICT-integrated professional skills. In higher education, $100 \%$ of students completing their foundation year at university were asked to acquire professional level ICT skills. Teaching training centers were asked to develop electronic training materials and pre-service teachers were asked to acquire ICT-integrated teaching skills (MoEYS 2009).

Although MoYES has made a significant effort to promote the usage of ICT in education, practitioners acknowledge that satisfactory changes have not been made in Cambodia. There must be a number of issues here, but in this paper, we focus on the role of teachers, especially in the secondary schools. Indeed, the effectiveness of ICT-integrated education is highly dependent on the motivation and capability of teachers (Eyal 2012; Luu and Freeman 2011; Yieng and Saat. 2013; Zhou, Hu and Gao 2010). Thus, we attempt to find answers to such questions as: What are the perceptions and beliefs of Cambodian teachers regarding the usefulness of ICT-integrated education? Do teachers have sufficient skills and confidence to take advantage of ICT-integrated education in their classes? In addition, this paper investigates whether there is a gender gap with respect to the use of ICT in educational settings, which can be regarded as another form of the digital divide. Indeed, such a gendered digital divide is more prominent in the developing countries (Nsibirano 2009). Accordingly, studying the sources of the gender gap between male and female teachers, and finding ways of bridging the gap, has become an urgent issue in developing countries.

To address theses questions, we collected survey data and performed statistical analyses to examine the perceptions, beliefs, and behaviors of teachers regarding ICT-integrated education in Cambodia. Based on our findings, we discuss policy implications, particularly with respect to the better utilization of the potential of ICT-integrated education by training and empowering teachers. Such information will be useful when we consider some possible steps for improving the quality of secondary education in Cambodia and other developing countries.

\section{LITERATURE REVIEW}

\section{ICT and Education}

ICT can be defined as "a diverse set of technological tools and resources used to communicate and to create, disseminate, store and manage information" (Tinio 2002,4). ICT encompasses not only conventional technologies such as the television and telephone, but also the latest computer and Internet-based technologies such as video conferences, e-mails and blogs (UNESCO 2003).

In recent years, the use of ICT has rapidly grown across the world. Its role in 
the development dimensions is crucial, as it does much to provide and equalizing opportunities for marginalized groups and communities, and thereby leads to economic and social development (Byrne, Nicholson and Salem 2011; Qureshi 2011). ICT also enables inclusive and sustainable human development by providing people with access to information as well as opportunities to participate in the knowledge economy (UNESCO 2013).

Accordingly, the importance of integrating ICT in education system has been widely emphasized (e.g., Volman, Eck, Heemskerk and Kuiper 2005). ICT in education has two fundamental forms: ICT literacy education and ICT application education. The former term refers to education about computers and information communication. The latter term refers to an education in which ICT is employed to enhance learning in such subjects as mathematics, science, and foreign languages (KERIS 2006). There is a consensus that the use of ICT in a classroom setting can lead to a high quality education (Kaffash, Kargiban, Kargiban and Ramezani 2010; Khan, Hasan and Clement 2012).

A number of researchers have pointed out the advantages of using ICT tools for educational purposes (Bruce and Levin 2003; Kaffash, Kargiban, Kargiban and Ramezani 2010; Khan, Hasan and Clement 2012; Luu and Freeman 2011; Yaacob, Iskandar and Jusoff 2011). First, ICT can provide easily accessible, high quality education to everyone including children in rural areas and people with physical disabilities, thereby meeting the goal of "education for all" (Kwapong 2009). Second, students can acquire knowledge through ICT in an active, self-directed and constructive manner (Bruce and Levin 2003; Khan, Hasan and Clement 2012; Volman and Edith 2001). For example, Cunska and Savicka (2012) argue that ICT integration in a math class can increase students' levels of understanding. Moreover, given the interactive nature of ICT, students' capabilities such as creativity, critical thinking, problem-solving, decision-making, communication skills, and collaboration skills can be improved (Volman and Edith 2001; Yaacob, Iskandar and Jusoff 2011). Third, ICT can be used to upgrade learning contents (Aristovnik 2012) and to improve the quality of teacher training (Tinio 2002). ICT-integrated education also can help teachers and students gain access to diverse information, share ideas, and collaborate on joint projects, and conduct lessons with little geographical constraint (UNESCO 2010).

\section{ICT-integrated Education in Developing Countries}

ICT can be considered a fundamental development tool for developing countries (Rambousek, Stipek, and Wildova 2012). According to the United Nations Group on the Information Society (UNGIS) regarding the Post-2015 Development Agenda, developing countries should fully utilize ICT in order to achieve sustainable development. The Dakar Framework for Action also stressed the use of ICT to help learners reach the "Education for All (EFA)" goals, and suggested that ICT has 
great potential when it comes to knowledge dissemination, effective learning and the development of more efficient educational services (Assar et al. 2010; Khan et al. 2012). Not surprisingly, researchers have documented the relationship between ICT-integrated education systems and the economic development of a developing country (Ukpe 2013).

The level of ICT-integrated education varies across countries. UNESCO (2010) identifies four stages of the ICT-integrated education: the emerging, applying, infusion, and transforming stages. In the emerging stage, schools are introduced to ICT infrastructure, either donated or purchased. Teachers explore the possibilities of using ICT for teaching. In the applying stage, schools come to understand the effectiveness of ICT in education. Teachers begin to revise their curricula so as to increase the use of ICT in the various subject areas, by utilizing software tools such as drawing, designing, modeling and simulations in their teaching. The infusion stage involves integrating ICT all across the curriculum. Teachers explore the many ways in which ICT is augmenting their personal productivity and altering their professional practices. In the transforming stage, ICT becomes integral not only throughout the curriculum but also the daily activities and pro-fessional practices of teachers and staff.

In many developing countries, ICT-integrated education is still in its early stage, and thus, the role of teachers should be more emphasized (Khan, Hasan and Clement 2012). For example, Yieng and Saat (2013), who studied the use of ICT in science instruction in Malaysia, observed that the teachers used computer software inappropriately and that the students had only a weak ability to apply the skills of reasoning. In such cases, the use of ICT in a classroom does not necessarily improve the quality of education (Luu and Freeman 2011). If the effectiveness of ICT-integrated education in developing countries is to be enhanced, therefore, more attention should be paid to the role of teachers.

Prior researchers have sought to determine what stimulates teachers to better integrate ICT into their pedagogical practices. For example, Albirini (2006) examined the relationship between teachers' computer attitudes and five independent variables: computer attributes, cultural perceptions, computer competence, computer access, and personal characteristics. The findings imply that the teachers' visions of and experiences with ICT, plus the cultural conditions that surround its introduction into schools, do much to shape their attitudes toward technology and to facilitate its subsequent diffusion throughout their educational practice. Drent and Meelissen (2008) also sought to determine which factors influence teacher's ICT usage. They found that teachers' personal characteristics play an important role in achieving the effective integration of ICT in the classroom. Yet, studies performed in developed countries may be less applicable to addressing the issues observed in classrooms in developing countries.

Teachers in developing countries often face a number of barriers to ICTintegrated education. Bingimlas (2009) argued that the integration of ICT into 
teaching is a complex process, one that involves school-level and teacher-level barriers. According to Morris (2010) and Khan, Hasan and Clement (2012), the school-level barriers include insufficient teacher training and technical support as well as inadequate ICT infrastructure (e.g., outdated and/or insufficient computers, bad internet connection, a lack of electricity, and a lack of access to ICT-related resources and materials). By contrast, the teacher-level barriers include insufficient teacher awareness as to which technologies are available, and a dearth of selfconfidence and competence, and a lack of ideas on how to take advantage of ICT in the classroom (Bingimlas 2009; Morris 2010; Rubagiza, Were and Sutherland 2011; Tondeur, Keer, Braak and Valcke 2008). In low-income countries, the high cost of ICT-integrated education and language barriers (e.g., inability to process information written in English) can also pose further challenges (Anzalone 2001).

Some research categorizes the barriers into three types: manipulative, nonmanipulative, and teacher-related factors. Manipulative factors include beliefs, skills, and commitment of teachers, ICT knowledge, and availability of ICT resources; non-manipulative factors include age, gender, religion, educational experience, computer experience, national policy, and external supports. In sum, these categorizations imply that the effectiveness of ICT-integrated education is affected not by one factor, but rather by several interrelated factors (Tedla 2012).

\section{Gender and ICT in Education}

ICT can help to enhance gender equality by increasing women's access to education and income-generating activities, allowing them to benefit from technological advances (World Bank 2009). ICT also can contribute to the empowerment of women by enhancing their IT skills (UNESCO 2003). Given all of this, it is not surprising that gender has become one of the key issues in ICT-integrated education.

Unfortunately, the potential of ICT-integrated education to help women has not been fully realized. In developing countries, women have less access to ICT and fewer opportunities for ICT-related training as compared to men, because of poverty, illiteracy, insufficient education, and lack of time and mobility (Tinio 2002). Accordingly, females in developing countries have been relatively marginalized and are not well-represented in computer courses, computer use, and computerrelated careers (Agbatogun 2009). As a result, a number of female school teachers in developing countries remain resistant to the use of technology in the classroom. By contrast, male teachers tend to have more positive attitudes, higher selfconfidence, and stronger competence in ICT-incorporated education than do their female counterparts (Volman and Eck 2001; Zhou, Hu and Gao 2010). This can have a negative impact on the confidence levels and attitudes of female students, for female teachers can be regarded as their role models, and the result is a gender gap in ICT usage.

Clearly, then, more exposure to ICT-related experience and training programs 
should be provided to female students and teachers in developing countries. As that exposure is offered, however, the unique characteristics of women should be taken into consideration. For example, Gomleksiz (2012) found that male students consider learning technology more necessary and important than do female students. Heemskerk et al. (2011) also found that students' interests and attitudes toward ICT are influenced by gender. More specifically, female students generally reported having fewer ICT skills and less ICT knowledge than did the male students. Volman et al. (2005) found that there are two main differences between boys and girls regarding ICT use; one is their usage time at home, and the other is interest. For example, teenage girls use the computer less at home and are less interested in programming or games than are boys. On the other hand, both genders use computers equally intensively in school, although girls use e-mail more frequently, while boys are more interested in playing games. Moreover, female students appreciate those ICT applications that address interesting subjects in an easy manner and while providing effective support. Such gender differences should be taken into consideration by anyone seeking to bring or to improve ICTintegrated education in a developing country.

\section{DATA AND ANALYSIS}

\section{Survey Questionnaires}

The quantitative analysis was performed by using the primary data that was collected for about two weeks in January 2014 by administering survey questionnaires to teachers $(\mathrm{N}=121)$ from six secondary schools (Grade 10-12) in Phnom Penh, Cambodia. The questionnaires consist of three sections. The first section relates to respondents' knowledge of and access to ICT, and their perceptions of ICT-integrated education; the second section seeks to elicit respondents' opinions regarding ICT integration in their institutions; and the final section is about respondents' backgrounds and demographics.

In the questionnaire's introduction, respondents were informed about the purpose of the study and told that its results would be used strictly for academic purposes, and that their personal information or details would be protected. The questionnaires include items on a 5-point Likert scale in order to measure the degree to which the respondents agree or disagree with statements regarding ICTintegrated education. In addition, open-ended questions were asked to identify possible issues that might hinder them from fully utilizing ICT tools in the classroom as well as to collect ideas about how best to overcome the issues.

Analysis of the data in this study is divided into two parts. The first part presents the descriptive statistics (e.g., frequency, \% distribution, mean, standard deviation) regarding the role of ICT-integrated education in the classroom. The second part adopts ANOVA analysis to assess the potential gender differences 
between male and female teachers regarding their degree of confidence in their ICT skills as well as their perceptions and beliefs associated with ICT-integrated education. For statistical analysis, SPSS 22.0 was used.

\section{Descriptive Statistics}

As shown in Table 1, among the 121 teacher participants, $62 \%$ were male and $38 \%$ female. In addition, $13 \%$ of the teacher respondents were in their twenties; $42 \%$ in their thirties; $38 \%$ in their forties and $7 \%$ in their fifties or above. With regard to level of education, $37 \%$ held a bachelor's degree while $26 \%$ held a master's degree. On average, the teacher respondents had more than 12 years of teaching experience. A majority of teachers (89\%) had a computer at home, and $65 \%$ said they felt confident about using a computer. A slight majority, 55\%, had a viable Internet connection. However, the level of computer usage in teaching varied widely: never (29\%), sometimes (29\%), usually (17\%), most of the time $(16 \%)$, and always $(9 \%)$.

TABLE 1. PROFILE OF TEACHER RESPONDENTS

\begin{tabular}{|c|c|c|c|}
\hline & & Frequency & $\%$ \\
\hline \multirow[t]{2}{*}{ Gender } & Male & 75 & 62 \\
\hline & Female & 46 & 38 \\
\hline \multirow{5}{*}{ Age } & $20-29$ & 16 & 13 \\
\hline & $30-39$ & 51 & 42 \\
\hline & $40-49$ & 47 & 38 \\
\hline & 50 and above & 8 & 7 \\
\hline & High school degree & 45 & 37 \\
\hline \multirow[t]{2}{*}{ Level of Education } & Bachelor's degree & 45 & 37 \\
\hline & Master's degree & 31 & 26 \\
\hline \multirow{5}{*}{ Teaching experience } & Less than 5 years & 19 & 16 \\
\hline & $5-9$ years & 28 & 23 \\
\hline & $10-14$ years & 25 & 20 \\
\hline & $15-19$ years & 20 & 16 \\
\hline & 20 years and above & 29 & 34 \\
\hline \multirow{2}{*}{ Computer at home } & Yes & 108 & 89 \\
\hline & No & 13 & 11 \\
\hline \multirow{2}{*}{ Internet connection } & Yes & 66 & 55 \\
\hline & No & 55 & 45 \\
\hline \multirow{5}{*}{ Use computer in my teaching } & Never & 35 & 29 \\
\hline & Sometimes & 35 & 29 \\
\hline & Usually & 20 & 17 \\
\hline & Most of the time & 19 & 16 \\
\hline & Always & 12 & 9 \\
\hline
\end{tabular}


Table 2 displays the teachers' self-confidence level with respect to their ICT skills in 10 dimensions. Around 50-70\% agreed (either "strongly agree" or "somewhat agree") that they felt confident about doing simple tasks such as saving files in computer folders, downloading files from the Internet, searching information via the Internet, using e-mail, and using word processing software. Only 43\%, however, felt confident about using spreadsheet software, while $31 \%$ were confident about using presentation software and $29 \%$ about creating multi-media presentations.

TABLE 2. TEACHERS' SELF-CONFIDENCE IN ICT SKILLS

\begin{tabular}{|c|c|c|c|c|c|}
\hline & $\begin{array}{l}\text { Strongly } \\
\text { Disagree }\end{array}$ & $\begin{array}{l}\text { Somewhat } \\
\text { Disagree }\end{array}$ & Neutral & $\begin{array}{l}\text { Somewhat } \\
\text { Agree }\end{array}$ & $\begin{array}{c}\text { Strongly } \\
\text { Agree }\end{array}$ \\
\hline \multirow{2}{*}{$\begin{array}{l}\text { Saving electronic documents in computer } \\
\text { folders }\end{array}$} & 12 & 10 & 19 & 52 & 26 \\
\hline & $10 \%$ & $8 \%$ & $16 \%$ & $44 \%$ & $22 \%$ \\
\hline \multirow{2}{*}{ Searching information by using the Internet } & 6 & 19 & 23 & 46 & 27 \\
\hline & $5 \%$ & $16 \%$ & $19 \%$ & $38 \%$ & $22 \%$ \\
\hline \multirow{2}{*}{ Downloading files from the Internet } & 8 & 22 & 29 & 38 & 24 \\
\hline & $7 \%$ & $18 \%$ & $24 \%$ & $31 \%$ & $20 \%$ \\
\hline \multirow{2}{*}{ Using E-mail } & 14 & 14 & 31 & 35 & 27 \\
\hline & $12 \%$ & $12 \%$ & $25 \%$ & $29 \%$ & $22 \%$ \\
\hline Using word processing software (e.g., MS & 13 & 11 & 32 & 39 & 26 \\
\hline Word) & $11 \%$ & $9 \%$ & $26 \%$ & $32 \%$ & $22 \%$ \\
\hline \multirow{2}{*}{ Using spreadsheet software (e.g., MS Excel) } & 21 & 21 & 29 & 26 & 24 \\
\hline & $17 \%$ & $17 \%$ & $24 \%$ & $23 \%$ & $20 \%$ \\
\hline Using presentation software (e.g., MS & 36 & 22 & 25 & 22 & 16 \\
\hline PowerPoint) & $30 \%$ & $18 \%$ & $21 \%$ & $18 \%$ & $13 \%$ \\
\hline \multirow{2}{*}{ Editing digital photographs or graphic images } & 46 & 21 & 24 & 20 & 10 \\
\hline & $38 \%$ & $17 \%$ & $20 \%$ & $17 \%$ & $8 \%$ \\
\hline \multirow{2}{*}{$\begin{array}{l}\text { Creating multimedia presentation (e.g., video, } \\
\text { animation) }\end{array}$} & 42 & 18 & 25 & 23 & 13 \\
\hline & $35 \%$ & $15 \%$ & $21 \%$ & $19 \%$ & $10 \%$ \\
\hline \multirow{2}{*}{ Creating and analyzing database } & 36 & 18 & 24 & 27 & 16 \\
\hline & $30 \%$ & $15 \%$ & $20 \%$ & $22 \%$ & $13 \%$ \\
\hline
\end{tabular}

Teachers' perceptions of ICT-integrated education were generally positive as summarized in Table 3. Of the teachers, 86\% agreed that ICT helped them find useful resources for their teaching and 79\% said that ICT facilitated their preparation of their lessons. Also, 74\% said that ICT improved teaching quality and effectiveness while $80 \%$ said that ICT made their lessons more interesting. Furthermore, 66\% said that ICT caused students to concentrate more and promoted collaborative learning. Interestingly, 73\% said that ICT improved their students' career prospects. Only $18 \%$ said that ICT made it hard to control the class, while $24 \%$ said that ICT was less effective than traditional learning methods.

Table 4 indicates the beliefs of teachers on the impacts of ICT-integrated education. Teachers agreed that ICT-integrated education would positively affect students' learning in terms of creativity (79\%), higher-order thinking skills $(69 \%)$, 
competence in ICT-related knowledge and skills (77\%), motivation (83\%), independent problem solving (68\%), academic achievement $(68 \%)$, and job prospects $(79 \%)$.

TABLE 3. TEACHERS' PerCEPTIONS OF ICT-INTEGRATED EDUCATION

\begin{tabular}{|c|c|c|c|c|c|}
\hline & $\begin{array}{l}\text { Strongly } \\
\text { Disagree }\end{array}$ & $\begin{array}{l}\text { Somewhat } \\
\text { Disagree }\end{array}$ & Neutral & $\begin{array}{l}\text { Somewhat } \\
\text { Agree }\end{array}$ & $\begin{array}{c}\text { Strongly } \\
\text { Agree }\end{array}$ \\
\hline \multirow{2}{*}{$\begin{array}{l}\text { Helps teachers find useful resources for } \\
\text { teaching }\end{array}$} & 3 & 2 & 12 & 66 & 38 \\
\hline & $2 \%$ & $2 \%$ & $10 \%$ & $55 \%$ & $31 \%$ \\
\hline \multirow{2}{*}{ Helps teachers prepare the lesson easily } & 2 & 5 & 19 & 65 & 30 \\
\hline & $2 \%$ & $4 \%$ & $15 \%$ & $54 \%$ & $25 \%$ \\
\hline \multirow{2}{*}{ Helps teachers explain the concepts better } & 3 & 4 & 35 & 57 & 22 \\
\hline & $2 \%$ & $3 \%$ & $29 \%$ & $48 \%$ & $18 \%$ \\
\hline \multirow{2}{*}{$\begin{array}{l}\text { Helps teachers promote collaborative } \\
\text { learning }\end{array}$} & 8 & 4 & 28 & 62 & 17 \\
\hline & $7 \%$ & $3 \%$ & $24 \%$ & $52 \%$ & $14 \%$ \\
\hline \multirow{2}{*}{$\begin{array}{l}\text { Helps teachers to make lessons more } \\
\text { interesting }\end{array}$} & 3 & 5 & 15 & 60 & 37 \\
\hline & $3 \%$ & $4 \%$ & $13 \%$ & $49 \%$ & $31 \%$ \\
\hline \multirow{2}{*}{ Improves teaching quality and effectiveness } & 2 & 5 & 24 & 62 & 28 \\
\hline & $2 \%$ & $4 \%$ & $20 \%$ & $51 \%$ & $23 \%$ \\
\hline \multirow{2}{*}{ Helps students concentrate on teaching } & 4 & 9 & 32 & 54 & 22 \\
\hline & $3 \%$ & $7 \%$ & $26 \%$ & $46 \%$ & $18 \%$ \\
\hline \multirow{2}{*}{ Helps teachers control the class easily } & 5 & 18 & 38 & 39 & 20 \\
\hline & $4 \%$ & $14 \%$ & $32 \%$ & $33 \%$ & $17 \%$ \\
\hline \multirow{2}{*}{$\begin{array}{l}\text { Is more effective than traditional learning } \\
\text { methods }\end{array}$} & 5 & 23 & 31 & 39 & 21 \\
\hline & $4 \%$ & $20 \%$ & $26 \%$ & $32 \%$ & $18 \%$ \\
\hline
\end{tabular}

TABLE 4. TEACHERS' BELIEFS ON THE IMPACTS OF ICT-INTEGRATED EDUCATION

\begin{tabular}{lrrrrr}
\hline & $\begin{array}{c}\text { Strongly } \\
\text { Disagree }\end{array}$ & $\begin{array}{c}\text { Somewhat } \\
\text { Disagree }\end{array}$ & Neutral & $\begin{array}{c}\text { Somewhat } \\
\text { Agree }\end{array}$ & $\begin{array}{c}\text { Strongly } \\
\text { Agree }\end{array}$ \\
\hline \multirow{2}{*}{ Students' creativity } & 6 & 0 & 20 & 61 & 32 \\
& $4 \%$ & $0 \%$ & $17 \%$ & $51 \%$ & $28 \%$ \\
\hline \multirow{2}{*}{ Students' higher order thinking skills } & 5 & 4 & 29 & 60 & 22 \\
& $4 \%$ & $3 \%$ & $24 \%$ & $51 \%$ & $18 \%$ \\
\hline Students' competence in ICT-related & 3 & 1 & 23 & 63 & 30 \\
knowledge and skills & $3 \%$ & $1 \%$ & $19 \%$ & $52 \%$ & $25 \%$ \\
\hline \multirow{2}{*}{ Students' motivation of learning } & 4 & 2 & 15 & 57 & 42 \\
& $3 \%$ & $2 \%$ & $12 \%$ & $48 \%$ & $35 \%$ \\
\hline Students' ability to solve problems & 5 & 4 & 30 & 57 & 24 \\
independently & $4 \%$ & $3 \%$ & $25 \%$ & $48 \%$ & $20 \%$ \\
\hline \multirow{2}{*}{ Students' academic achievement } & 6 & 9 & 24 & 60 & 20 \\
& $5 \%$ & $7 \%$ & $20 \%$ & $51 \%$ & $17 \%$ \\
\hline \multirow{2}{*}{ Students' job prospect } & 6 & 2 & 17 & 62 & 33 \\
& $5 \%$ & $2 \%$ & $14 \%$ & $51 \%$ & $28 \%$ \\
\hline
\end{tabular}

Even though teachers' perceptions of ICT education and their beliefs as to its effectiveness were positive, Table 5 shows that the integration level of ICT into teaching was quite limited. More than $70 \%$ of teachers never used or used com- 
puters or other ICT tools just once in a week in the classroom, exception with the word processing software for testing and grading.

\section{TABLE 5. TEACHERS' USAGE OF ICT IN THE ClASSROOM (\# OF DAYS PER WEEK)}

\begin{tabular}{|c|c|c|c|c|c|c|c|}
\hline & None & 1 & 2 & 3 & 4 & 5 & 6 \\
\hline Presentation software (e.g., MS & 76 & 12 & 7 & 10 & 7 & 4 & 2 \\
\hline PowerPoint) & $65 \%$ & $10 \%$ & $6 \%$ & $8 \%$ & $6 \%$ & $3 \%$ & $2 \%$ \\
\hline \multirow{2}{*}{$\begin{array}{l}\text { Word processing software (e.g., } \\
\text { MSWord) }\end{array}$} & 59 & 12 & 17 & 19 & 7 & 3 & $\overline{4}$ \\
\hline & $49 \%$ & $10 \%$ & $14 \%$ & $16 \%$ & $6 \%$ & $2 \%$ & $3 \%$ \\
\hline \multirow{2}{*}{$\begin{array}{l}\text { Spreadsheet software (e.g., MS } \\
\text { Excel) }\end{array}$} & 75 & 15 & 10 & 9 & 9 & 1 & 1 \\
\hline & $63 \%$ & $12 \%$ & $8 \%$ & $8 \%$ & $7 \%$ & $1 \%$ & $1 \%$ \\
\hline \multirow{2}{*}{ Graphic design software } & 90 & 7 & 9 & 7 & 3 & 3 & 0 \\
\hline & $76 \%$ & $6 \%$ & $8 \%$ & $6 \%$ & $2 \%$ & $3 \%$ & $0 \%$ \\
\hline \multirow{2}{*}{ Video clips (e.g., YouTube) } & 86 & 16 & 5 & 5 & 4 & 3 & 0 \\
\hline & $73 \%$ & $13 \%$ & $4 \%$ & $4 \%$ & $3 \%$ & $2 \%$ & $0 \%$ \\
\hline \multirow{2}{*}{ Educational CDs/VCDs } & 90 & 6 & 6 & 8 & 6 & 1 & 0 \\
\hline & $77 \%$ & $5 \%$ & $5 \%$ & $7 \%$ & $5 \%$ & $1 \%$ & $0 \%$ \\
\hline \multirow{2}{*}{ Problem solving and reasoning } & 67 & 18 & 9 & 15 & 7 & 3 & 1 \\
\hline & $56 \%$ & $15 \%$ & $8 \%$ & $12 \%$ & $6 \%$ & $2 \%$ & $1 \%$ \\
\hline \multirow{2}{*}{ Testing and grading } & 49 & 21 & 16 & 14 & 9 & 7 & $\overline{4}$ \\
\hline & $41 \%$ & $18 \%$ & $13 \%$ & $12 \%$ & $7 \%$ & $6 \%$ & $3 \%$ \\
\hline
\end{tabular}

Table 6 provides the reasons that teachers' usage of ICT tools was limited in their teaching. Teachers pointed out various impediments related to ICT infrastructure including lack of electricity $(66 \%)$, insufficient internet connection $(63 \%)$, insufficient number of computers $(60 \%)$, and obsolete school computers (51\%). Other challenges they mentioned included lack of contents in the national language (68\%), insufficient technical support for teachers $(67 \%)$, lack of teacher training (60\%), lack of funding (68\%), difficulty in integrating ICT into a large class (54\%), and lack of adequate teacher skills (54\%). Yet, only $41 \%$ pointed to a lack of teaching interest as being the problem. Taken together, such findings, which reveal that teachers' interest is considerable, suggest that if sufficient ICT infrastructure, other related technical supports, and teacher training programs are provided, ICT-integrated education would be more actively deployed.

To further investigate which types of skills teacher training programs should provide, we asked some extra questions regarding teachers' confidence in using ICT in the classroom. Table 7 illustrates that $59 \%$ of the teacher respondents felt confident about using the Internet to find sources and materials for their teaching. On the other hand, the confidence level of teachers in teaching students how to use ICT in class (28\%) and in designing effective ICT learning activities (28\%) was much lower, implying that teachers have a low capacity to implement ICT integration into their classrooms. This can surely hamper the effectiveness of ICTintegrated education in Cambodia. 
TABLE 6. BARRIERS TO ADOPTING ICT-INTEGRATED EDUCATION IN THE CLASSROOM

\begin{tabular}{lrrrrr}
\hline & $\begin{array}{c}\text { Not important } \\
\text { at all }\end{array}$ & $\begin{array}{c}\text { Somewhat } \\
\text { important }\end{array}$ & $\begin{array}{c}\text { Important } \\
\text { Obuite }\end{array}$ & $\begin{array}{c}\text { Very } \\
\text { Important }\end{array}$ \\
\hline \multirow{2}{*}{ Important }
\end{tabular}

TABLE 7. TEACHERS' CONFIDENCE IN USING ICT IN THE ClASSROOM

\begin{tabular}{lrrrrr}
\hline & $\begin{array}{c}\text { Strongly } \\
\text { Disagree }\end{array}$ & $\begin{array}{c}\text { Somewhat } \\
\text { Disagree }\end{array}$ & Neutral & $\begin{array}{c}\text { Somewhat } \\
\text { Agree }\end{array}$ & $\begin{array}{c}\text { Strongly } \\
\text { Agree }\end{array}$ \\
\hline Using the Internet to find sources and & 15 & 13 & 22 & 43 & 28 \\
materials for teaching & $12 \%$ & $11 \%$ & $18 \%$ & $36 \%$ & $23 \%$ \\
\hline Teaching students how to use ICT in the & 28 & 27 & 31 & 25 & 9 \\
classroom & $23 \%$ & $23 \%$ & $26 \%$ & $21 \%$ & $7 \%$ \\
\hline Designing effective ICT-based learning & 26 & 24 & 36 & 29 & 6 \\
activities for my students & $22 \%$ & $20 \%$ & $30 \%$ & $24 \%$ & $4 \%$ \\
\hline
\end{tabular}

TABLE 8. TEACHERS' SUGgeStIONS TO OVERCOME THE BARRIERS

\begin{tabular}{lc}
\hline & Frequency \\
\hline Providing teacher training on ICT & 81 \\
\hline Sufficient computers and facilities & 73 \\
\hline Sufficient electricity accessibility & 13 \\
\hline Sufficient internet accessibility & 13 \\
\hline Sufficient financial support & 13 \\
\hline Integrating ICT since the primary level & 13 \\
\hline Setting specific objectives for ICT education & 10 \\
\hline Sufficient time allocation & 8 \\
\hline
\end{tabular}


Suggestions for overcoming the aforementioned barriers were obtained from the open-ended questions and listed in Table 8. Two of the most frequent suggestions were providing teacher training in ICT skills and knowledge (81 participants) and presenting sufficient computers and facilities ( 73 participants). Besides, there are also other infrastructural factors such as the Internet, electricity, and financial support that need to be provided together. Ultimately, providing proper teacher training and sufficient equipment seem to be most urgent tasks, if we wish to success fully integrate ICT into the teaching and learning process.

\section{Gender and ICT-integrated Education}

In and of itself, ICT-integrated education is perceived by teachers as being both useful and important. However, the usage and integration of ICT in the classroom remains limited in Cambodia. To resolve this problem, one of the most important tasks is to offer the proper teacher training programs. When we design such programs, however, we need to consider possible gender related differences. In this section, we performed ANOVA analyses to identify gender differences between male and female teachers.

TABLE 9. TEACHERS' PERCEPTIONS OF ICT-INTEGRATED EDUCATION BY GENDER

\begin{tabular}{|c|c|c|c|c|c|}
\hline & Sex & Mean & Std Dev & $\mathrm{F}$ & Sig. \\
\hline \multirow{2}{*}{$\begin{array}{l}\text { Is more effective than traditional learning } \\
\text { methods }\end{array}$} & Female & 3.378 & 1.072 & \multirow{2}{*}{.038} & \multirow{2}{*}{.846} \\
\hline & Male & 3.419 & 1.146 & & \\
\hline \multirow{2}{*}{$\begin{array}{l}\text { Helps teachers promote collaborative } \\
\text { learning }\end{array}$} & Female & 3.733 & .687 & \multirow{2}{*}{.650} & \multirow{2}{*}{.422} \\
\hline & Male & 3.581 & 1.146 & & \\
\hline \multirow{2}{*}{$\begin{array}{l}\text { Helps teachers find useful resources for } \\
\text { teaching }\end{array}$} & Female & 4.078 & .626 & \multirow{2}{*}{.044} & \multirow{2}{*}{.834} \\
\hline & Male & 4.120 & .943 & & \\
\hline \multirow{2}{*}{ Helps teachers explain the concepts better } & Female & 3.760 & .108 & \multirow{2}{*}{.007} & \multirow{2}{*}{.932} \\
\hline & Male & 3.746 & .110 & & \\
\hline \multirow{2}{*}{ Improves teaching quality and effectiveness } & Female & 3.869 & .718 & \multirow{2}{*}{.097} & \multirow{2}{*}{.756} \\
\hline & Male & 3.920 & .940 & & \\
\hline \multirow{2}{*}{ Helps teachers prepare the lesson easily } & Female & 3.913 & .724 & \multirow{2}{*}{.212} & \multirow{2}{*}{.646} \\
\hline & Male & 3.986 & .922 & & \\
\hline \multirow{2}{*}{$\begin{array}{l}\text { Helps teachers to make lessons more } \\
\text { interesting }\end{array}$} & Female & 4.021 & .649 & \multirow{2}{*}{.001} & \multirow{2}{*}{.976} \\
\hline & Male & 4.025 & 1.046 & & \\
\hline \multirow{2}{*}{ Helps teachers control the class easily } & Female & 3.196 & 1.185 & \multirow{2}{*}{3.524} & \multirow{2}{*}{.063} \\
\hline & Male & 3.568 & .966 & & \\
\hline \multirow{2}{*}{ Helps students concentrate on teaching } & Female & 3.673 & .844 & \multirow{2}{*}{.002} & \multirow{2}{*}{.968} \\
\hline & Male & 3.666 & 1.044 & & \\
\hline
\end{tabular}


With regard to teachers' perceptions of the usefulness of ICT-integrated education, Table 9 indicates that there is no significant difference between male and female teachers, for their means show similar values and the level of significance ( $p$-value) is greater than .05. This means that both genders have similar perceptions of the usefulness of ICT in education. In particular, both male and female teachers perceive that ICT-integration helps them find resources for their teaching and to make their lessons more interesting.

As for belief with regard to the impact of ICT-integrated education on students' performance, again there is no gender difference at the $5 \%$ significance level as shown in Table 10. The only exception is the belief in the impact on students' academic achievement of ICT-integrated education; male teachers' belief (3.835) is higher than that of female teachers (3.391) and this difference is significant ( $\mathrm{p}$-value $=.019)$.

TABLE 10. TEACHERS’ BELIEFS ON THE IMPACTS OF ICT-INTEGRATED EDUCATION BY GENDER

\begin{tabular}{|c|c|c|c|c|c|}
\hline & Sex & Mean & Std Dev & $\mathrm{F}$ & Sig. \\
\hline \multirow{2}{*}{ Students' academic achievement } & Female & 3.391 & 1.105 & \multirow{2}{*}{5.668} & \multirow{2}{*}{.019} \\
\hline & Male & 3.835 & .913 & & \\
\hline \multirow{2}{*}{$\begin{array}{l}\text { Students' competence in ICT-related } \\
\text { knowledge and skill }\end{array}$} & Female & 3.891 & .822 & \multirow{2}{*}{599} & \multirow{2}{*}{.440} \\
\hline & Male & 4.013 & .851 & & \\
\hline \multirow{2}{*}{ Students' creativity } & Female & 3.934 & .800 & \multirow{2}{*}{.018} & \multirow{2}{*}{.893} \\
\hline & Male & 3.958 & 1.033 & & \\
\hline \multirow{2}{*}{ Students' higher order thinking skills } & Female & 3.760 & .873 & \multirow{2}{*}{.010} & \multirow{2}{*}{.921} \\
\hline & Male & 3.743 & .980 & & \\
\hline \multirow{2}{*}{$\begin{array}{l}\text { Students' ability to solve problems } \\
\text { independently }\end{array}$} & Female & 3.739 & .929 & \multirow{2}{*}{.030} & \multirow{2}{*}{.863} \\
\hline & Male & 3.770 & .972 & & \\
\hline \multirow{2}{*}{ Students' motivation of learning } & Male & 4.000 & .843 & \multirow{2}{*}{.744} & \multirow{2}{*}{.390} \\
\hline & Female & 4.091 & .960 & & \\
\hline \multirow{2}{*}{ Students' job prospect } & Female & 3.934 & .879 & \multirow{2}{*}{.018} & \multirow{2}{*}{.893} \\
\hline & Male & 3.959 & 1.026 & & \\
\hline
\end{tabular}

Different from teachers' perceptions and beliefs regarding ICT-integrated education, Table 11 shows there are statistically significant differences between the male and female teachers in terms of their self-confidence in ICT skills ( $p$ $<.05)$. For example, male teachers' self-confidence in saving electronic documents in computer folders is 3.770 while that of female teachers is 3.288 . This difference is statistically significant $(\mathrm{F}$-stat $=4.561, \mathrm{p}$-value $=.035)$. Moreover, it seems that male teachers know better than the female teachers how to use word processing, spreadsheet, and presentation software $(\mathrm{p}<.01)$. Overall, the mean values of male teachers are greater than those of their female counterparts $(p<.05)$, implying that 
male teachers were more confident than female teachers with respect to all 10 dimensions of ICT skills.

TABLE 11: TEACHERS'SELF-CONFIDENCE IN ICT SKILLS BY GENDER

\begin{tabular}{|c|c|c|c|c|c|}
\hline & Sex & Mean & Std Dev & $\mathrm{F}$ & Sig. \\
\hline \multirow{2}{*}{$\begin{array}{l}\text { Saving electronic documents in } \\
\text { computer folders }\end{array}$} & Female & 3.288 & 1.198 & \multirow{2}{*}{4.561} & \multirow{2}{*}{.035} \\
\hline & Male & 3.770 & 1.188 & & \\
\hline \multirow{2}{*}{ Downloading files from the Internet } & Female & 3.087 & 1.170 & \multirow{2}{*}{5.235} & \multirow{2}{*}{.024} \\
\hline & Male & 3.586 & 1.163 & & \\
\hline \multirow{2}{*}{$\begin{array}{l}\text { Searching information by using the } \\
\text { Internet }\end{array}$} & Female & 3.021 & 1.105 & \multirow{2}{*}{19.634} & \multirow{2}{*}{.000} \\
\hline & Male & 3.906 & 1.042 & & \\
\hline \multirow{2}{*}{ Emailing } & Female & 2.978 & 1.201 & \multirow{2}{*}{8.152} & \multirow{2}{*}{.005} \\
\hline & Male & 3.640 & 1.258 & & \\
\hline \multirow{2}{*}{$\begin{array}{l}\text { Using word processing software } \\
\text { (e.g., MS WORD) }\end{array}$} & Female & 3.043 & 1.264 & \multirow{2}{*}{8.436} & \multirow{2}{*}{.004} \\
\hline & Male & 3.693 & 1.150 & & \\
\hline \multirow{2}{*}{$\begin{array}{l}\text { Using spreadsheet software } \\
\text { (e.g., MS EXCEL) }\end{array}$} & Female & 2.630 & 1.235 & \multirow{2}{*}{8.906} & \multirow{2}{*}{.003} \\
\hline & Male & 3.373 & 1.383 & & \\
\hline \multirow{2}{*}{$\begin{array}{l}\text { Using presentation software } \\
\text { (e.g., MS PowerPoint) }\end{array}$} & Female & 2.217 & 1.245 & \multirow{2}{*}{8.070} & \multirow{2}{*}{.005} \\
\hline & Male & 2.946 & 1.441 & & \\
\hline \multirow{2}{*}{$\begin{array}{l}\text { Editing digital photographs or graphic } \\
\text { images }\end{array}$} & Female & 2.087 & 1.189 & \multirow{2}{*}{3.962} & \multirow{2}{*}{.049} \\
\hline & Male & 2.586 & 1.424 & & \\
\hline \multirow{2}{*}{$\begin{array}{l}\text { Creating multimedia presentation } \\
\text { (animation, video) }\end{array}$} & Female & 2.130 & 1.292 & \multirow{2}{*}{7.344} & \multirow{2}{*}{.008} \\
\hline & Male & 2.826 & 1.417 & & \\
\hline \multirow{2}{*}{ Creating and analyzing database } & Female & 2.413 & 1.359 & \multirow{2}{*}{4.078} & \multirow{2}{*}{.046} \\
\hline & Male & 2.946 & 1.441 & & \\
\hline
\end{tabular}

TABLE 12: TEACHER's CONFIDENCE IN USING ICT IN THE CLASSROOM BY GENDER

\begin{tabular}{|c|c|c|c|c|c|}
\hline & Sex & Mean & Std Dev & $\mathrm{F}$ & Sig. \\
\hline \multirow{2}{*}{$\begin{array}{l}\text { Teaching students how to use ICT in the } \\
\text { classroom }\end{array}$} & Female & 2.222 & 1.084 & \multirow{2}{*}{9.732} & \multirow{2}{*}{.002} \\
\hline & Male & 2.933 & 1.276 & & \\
\hline \multirow{2}{*}{$\begin{array}{l}\text { Designing effective ICT-based learning } \\
\text { activities for students }\end{array}$} & Female & 2.391 & 1.163 & \multirow{2}{*}{5.518} & \multirow{2}{*}{.020} \\
\hline & Male & 2.906 & 1.176 & & \\
\hline \multirow{2}{*}{$\begin{array}{l}\text { Using the Internet to find sources and } \\
\text { materials for teaching }\end{array}$} & Female & 2.956 & 1.246 & \multirow{2}{*}{12.366} & \multirow{2}{*}{.001} \\
\hline & Male & 3.773 & 1.236 & & \\
\hline
\end{tabular}

Table 12 shows that the confidence level of male teachers in using ICT tools in the classroom setting is significantly higher than that of female teachers $(\mathrm{p}$ $<.01)$. Specifically, the male teachers feel more confident when teaching students how to use ICT (female mean $=2.222$, male mean $=2.933$, $\mathrm{p}$-value $=.002$ ), when designing effective ICT-integrated learning activities for students $($ female mean $=$ 
2.391, male mean $=2.906$, $\mathrm{p}$-value $=.020$ ), and when using the Internet to find sources and materials for their teaching (female mean $=2.956$, male mean $=3.773$, p-value $=.001)$.

\section{DISCUSSION}

\section{Summary of Findings}

The twofold goal of this research is: 1) to explore the perceptions, beliefs, and behaviors of teachers in relation to the usage of ICT in Cambodia's secondary school system; and 2) to identify those challenges teachers are facing which may hinder them from implementing ICT-integrated education in the classroom setting. To achieve this goal, we performed a survey data analysis.

Our empirical findings suggest the following. First, ICT-integrated education is viewed positively by teachers, since it can improve the effectiveness of the teaching-learning process and ensure the education quality for secondary school system in Cambodia. More specifically, teachers are convinced that ICT-integrated education can assist them to teach better than traditional teaching methods as it helps them explain the concepts better and thereby improves teaching quality. Teachers also believe that ICT-integrated education can enhance students' createvity, higher-order thinking skills, motivation, and academic achievement, all of which are conducive to better job opportunities.

Second, in spite of teachers' positive perceptions of and beliefs in the usefulness of ICT-integrated education, ICT tools still are not being effectively used by them in classroom. The low level of ICT utilization in the classroom can be attributed to teachers' low ICT capacity, poor ICT infrastructure, and weak ICT support. Especially noteworthy is the fact that the teachers' self-confidence in utilizing ICT tools for their teaching was generally low. Consequently, they have difficulty finding appropriate sources and materials from the Internet, teaching students how to use ICT in the classroom, and designing effective ICT learning activities for their students. Thus, appropriate teacher training programs are needed to empower teachers.

Third, teachers consider the dearth of ICT-related infrastructure and support as constituting a significant barrier to ICT utilization in the classroom. Among the barriers or challenges are shortages of computers and facilities, poor Internet connections, deficient electricity, and lack of technical support and funding. Another barrier to the ICT-integrated education was the lack of ICT content in the national language and training for teachers.

Finally, the findings show that there are gender differences between male and female teachers when it comes to ICT-integrated education in Cambodia's seconddary schools. Interestingly, there was no difference between male and female 
teachers in terms of their perceptions of the usefulness of ICT-integrated education, or in their beliefs about its impacts on student performance. Male teachers, however, show a higher confidence level than do their female counterparts in basic ICT skills as well as in advanced skills when applying ICT tools to their classroom teaching.

\section{Conclusion and Policy Recommendations}

The active utilization of ICT is imperative if we are to meet the needs of students and to improve the quality of secondary education, thereby helping Cambodia to close the digital gaps inside and outside of the country. Accordingly, the integration of ICT into Cambodia's secondary school system has become one of the priorities of the Cambodian government (e.g., MoEYS 2009, 2014). Clearly, there is a pressing need to develop and implement policies and action plans.

Our findings show that Cambodian teachers are facing a number of significant challenges. More specifically, insufficient computers and facilities, poor Internet access, lack of electricity provision, and limited funding, coupled with the inadequate ICT skills of teachers, are the significant barriers impeding the progress of ICT integration within Cambodia's education system. To resolve these problems, sufficient budget should be allocated. According to Education Strategic Plan (ESP) 2014-2018 by MoEYS (2014), however, ICT-integrated education budget was just $\$ 64,159$ in 2013 , which amounts to only $0.23 \%$ of the total education budget of $\$ 280$ million in 2013. Yet, our survey results imply that Cambodia's ICT-integrated education is still in its early stage, located somewhere between emerging and applying stage according to the categorization by UNESCO (2010). Given that they have very small budget for ICT-integrated education, thus, more emphasis should be placed on building ICT-related infrastructure in the classroom.

In addition, ESP 2009-2013 by MoYES (2009) did not mention about the role of teachers in improving the effectiveness of ICT-integrated education. Rather, it focused on the development of ICT usage for administrative and data management purposes for staff in the ministry, meaning that MoEYS aimed to improve capacity building of educational staff in the central and provincial level. Our survey results, however, suggest that more ICT-integration should be achieved by enhancing the role of teachers in the classroom, instead of spending limited resources on capacity building of staff in the office. More specifically, well-designed professional development programs and workshops for teachers are called for in order to help teachers acquire ICT competency and to increase their confidence level in integrating ICT into their teaching. Teaching materials should be prepared in the national language so that teachers with limited foreign language skills can use such contents with ease. The government may want to develop an online 
platform through which teachers in both urban and rural areas can easily get access to diverse ICT-related contents. Our findings also imply that such teacher support resources and activities should pay more attention to female teachers at the secondary school level, many of whom are struggling to adapt themselves to today's ever-changing and fast-advancing technological environment.

To overcome these barriers, however, budget and effort exercised by MoEYS alone will not be sufficient. To provide sufficient equipment and proper teacher training, international-level public-private partnerships (PPP) among key players including MoEYS, schools, international organizations, NGOs, for-profit firms, and foreign governments is recommended, which will allow them to mobilize together institution-specific resources such as funding, technology, marketing, experience, and expertise so that the power of ICT for better education can be fully utilized in Cambodia.

\section{Limitations and Future Research}

This study is subject to several limitations. First, survey data analysis implicitly assumes that the participants state their true opinions. However, this assumeption is not always held because sometimes survey participants have less incentive to tell the truth in certain cases (e.g., controversial issues, face-saving reasons, etc.). Even though our participants, i.e., secondary school teachers, have little reason to tell a lie in our survey, still the outcome of survey data analysis should be carefully interpreted.

Second, the study would have been benefited greater if a mixed methodology research design was used. Because of time constraints and political turmoil in Cambodia during the data collection period, however, we couldn't perform indepth, face-to-face interviews. Future researchers may want to combine quantitative analysis and qualitative analysis to obtain a more complete picture.

Third, among the key benefits of ICT-integrated education, we did not cover governance and management of education system augmented by ICT, which is also a relevant and important research topic. We leave this task to future researchers.

Fourth, our sample size is 121, which may not be large enough. Indeed we wanted to collect more data; but Cambodia was into political turmoil when we administered survey, which prompted us to focus on 6 schools in our dataset. Even though such situation is not rare when we perform a survey or field study in a developing country, one should be careful before making any generalization based on our study.

Finally, our data is collected from Phnom Penh, the capital city where the level of ICT infrastructure and teacher quality is relatively high. So our results may be less applicable in the rural and poor areas where students have to share books, learn from less qualified teachers, and have no school building within a 
reasonable distance. Future researchers may want to perform a similar survey to ours in rural areas. In addition, the role of an online platform through which teachers in both urban and rural areas can easily gain access to diverse ICT-related contents may be another interesting and important topic for researchers as well as practitioners.

In sum, we emphasize the importance of building ICT infrastructure and producing capable teachers if there is to be successful implementation of ICTintegrated education in Cambodia's secondary schools. We hope this study offers insights as to how we may reconfigure resource allocation, develop necessary policies, and design teacher education programs, so as to enhance the quality of secondary education in Cambodia.

\section{REFERENCES}

Agbatogun, A. A. 2009. Gender Diversity and ICT Literacy Among Nigerian InService Teachers. Gender and Behaviour 7(2): 2485-2503.

Albirini, A. 2006. Teachers' Attitudes toward Information and Communication Technologies: The Case of Syrian EFL Teachers. Computers and Education 47: 373-398.

Assar, S., R. E. Amrarni, and R. T. Watson. 2010. ICT and Education: A Critical Role in Human and Social Development. Information Technology for Development 16(3):151-158.

Bingimlas, K. A. 2009. Barriers to the Successful Integration of ICT in Teaching and Learning Environments: A Review of the Literature. Eurasia Journal of Mathematics, Science and Technology Education 5(3): 235-245.

Bruce, B. C. and J. A. Levin. 2003. Roles for New Technologies in Language Arts: Inquiry, Communication, Construction, and Expression. In Handbook of Research on Teaching the English Language Arts, $2^{\text {nd }}$ edition, eds. J. Flood, D. Lapp, J. R. Squire, and J. R. Jensen. Mahwah, NJ: Lawrence Erlbaum.

Byrne, E., B. Nicholson, and F. Salem. 2011. Information Communication Technologies and the Millennium Development Goals. Information Technology for Development 17(1): 1-3.

Cabanatan, P. G. 2005. Using ICT in the Classroom: Status and Prospects in Southeast Asia. Asia-Pacific Cybereducation Journal 1(2): 65-72.

Cunska, A. and I. Savicka. 2012. Use of ICT Teaching-Learning Methods Make School Math Blossom. Procedia-Social and Behavioral Sciences 69: 14811488 .

Drent, M. and M. Meelissen. 2008. Which Factors Obstruct or Stimulate Teacher Educators to Use ICT Innovatively? Computers and Education 51: 187-199.

Ehrmann, S. C. 1994. Responding to the Triple Challenge Facing Post Secondary Education: Access, Quality, Costs, Report prepared for the OECD Interna- 
tional Conference, December 14-16, Paris.

Engel, J. 2010. Rebuilding Basic Education in Cambodia: Establishing a More Effective Development Partnership, London: Overseas Development Institute. Eyal, L. 2012. Digital Assessment Library-the Core Role of the Teacher in a Digital Environment. Educational Technology and Society 15(2): 37-49.

Gömleksiz, M. N. 2012. Elementary School Students' Perceptions of the New Science and Technology Curriculum by Gender. Educational Technology and Society 15(1): 116-126.

Kaffash, H. R., Z. A. Kargiban, S. A. Kargiban, and M. T. Ramezani. 2010. A Closer Look into the Role of ICT in Education. International Journal of Instruction 3(2): 63-82.

Khan, S. H., M. Hasan, and C. K. Clement. 2012. Barriers to the Introduction of ICT into Education in Developing Countries: The Example of Bangladesh. International Journal of Instruction 5(2): 61-80.

KERIS. 2006. Main Achievements for ICT use in Education in Korea 1996-2006. KERIS Special Report: e-learning International Cooperation Team.

Kwapong, O. A. and A. Frimpong. 2009. Comparing Knowledge and Usage of ICT among Male and Female Distance Learners of an Endowed and Deprived Area in a Developing Countries in Africa. Journal of Information Technology Education 8: 1-17.

Luu, K. and J. G. Freeman. 2011. An Analysis of the Relationship between Information and Communication Technology (ICT) and Scientific Literacy in Canada and Australia. Computer and Education 56: 1072-1082.

MoEYS. 2004. Policy and Strategy on Information and Technology in Education in Cambodia. Kingdom of Cambodia Ministry of Education, Youth, and Sports. Phnom Penh, Cambodia.

MoEYS. 2006. Education Strategic Plan 2006-2010. Kingdom of Cambodia Ministry of Education, Youth, and Sports. Phnom Penh, Cambodia.

MoEYS. 2009. Education Strategic Plan 2009-2013. Kingdom of Cambodia Ministry of Education, Youth, and Sports. Phnom Penh, Cambodia.

MoEYS. 2014. Education Strategic Plan 2014-2018. Kingdom of Cambodia Ministry of Education, Youth, and Sports. Phnom Penh, Cambodia.

Morris, D. 2010. Are Teachers Technophobes? Investigating Professional Competency in the Use of ICT to Support Teaching and Learning. ProcediaSocial and Behavioral Sciences 2: 4010-4015.

Nsibirano, R. 2009. Him and Her-Gender differentials in ICT uptake: A critical literature review and research agenda. International Journal of Education and Development using Information and Communication Technology 5(5): $33-42$.

Qureshi, S. 2011. Globalization in Development: Do Information and Communication Technologies Really Matter? Information Technology for Development 
17(4): 249-252.

Rambousek, V., J. Stipek, and R. Wildova. 2012. Research of ICT Literacy Education in the Czech Republic. Procedia Social and Behavioral Sciences 69: 1945-1951.

Rubagiza, J., E. Were, and R. Sutherland. 2011. Introducing ICT into School in Rwanda: Education Challenges and Opportunities. International Journal of Education Development 31: 37-43.

Seng, S. 2014. The Role of Information and Communication Technology (ICT) in Improving the Quality of Education in Cambodia: Learning from Korea's Experience, Masters' Thesis. Ewha Womans University.

Symaco, L. P. and C. Brock. 2013. Education in South-East Asia. Bloomsbury: New York.

Tedla, S. 2001. ICTs to Support Learning in Classrooms in SEAMEO Countries: At What Costs? Paper prepared for Southeast Asian Ministers of Education Organization (SEAMEO). Bangkok, Thailand.

Tedla, B. A. 2012. Understanding the Importance, Impacts and Barriers of ICT on Teaching and Learning in East African Countries. International Journal for e-Learning Security 2(3/4): 199-207.

Tinio, V. L. 2002. ICT in Education. New York: United Nations Development Programmme (UNDP), Bureau of Development Policy.

Tondeur, J., H. Keer, J. Braak, and M. Valcke. 2008. ICT Integration in the Classroom: Challenging the Potential of a School Policy. Computer and Education 51: 212-223.

Ukpe, E. 2013. ICT in Education: Catalyst for Economic Growth in Nigeria. International Journal of Education and Research 1(10): 1-8.

UNESCO. 2003. Building Capacity of Teachers/Facilitators in Technology-Pedagogy Integration for Improved Teaching and Learning UNESCO Implemented Project on Training and Professional Development of Teachers and Facilitators in the Effective Use of ICTS for Improved Teaching and Learning. Bangkok: Asia and Pacific Regional Bureau for Education.

UNESCO. 2004. Education for all: The Quality Imperative. Paris: UNESCO.

UNESCO. 2010. ICT Transforming Education: A Regional Guide. Bangkok: UNE SCO Asia and Pacific Regional Bureau for Education.

UNESCO. 2013. ICT in Education: Policy, Infrastructure and ODA Status in Selected ASEAN Countries. Bangkok: UNESCO.

Volman, M. and E. Eck. 2001. Gender Equity and Information Technology in Education: The Second Decade. Review of Educational Research 71(4): 613-634.

Volman, M., E. Eck, I. Heemsherk, and E. Kuiper. 2005. New Technologies, New Differences: Gender and Ethnic Differences in Pupil's Use of ICT in Primary and Secondary Education. Computer and Education 45: 35-55.

Voluntary Service Organization (VSO). 2010. Reaching the Un-reached: Bridging 
Social Divide in Cambodia through Inclusive Education.

Voogt, J. and K. Gerald. 2008. Springer International Handbook of Information Technology in Primary and Secondary Education. New York: Springer.

Wagner, D. A. 2010. Quality of Education, Comparability, and Assessment Choice in Developing Countries. A Journal of Comparative and International Education 40(6): 741-760.

World Bank. 2009. Information and Communications for Development 2009: Extending Reach and Increasing Impact. http:/go.worldbank.org/DMY979 SNP0.

Yaacob, R. A., R. A. Iskandar, K. Jusoff. 2011. Achieving Excellence through Information Literacy as Part of Innovative Curriculum. Journal of Arts Science and Commerce 2(1): 1-11.

Yieng, L. P. and R. M. Saat. 2013. Use of Information Communications Technology (ICT) in Malaysian Science Teaching: A Microanalysis of TIMSS 2011. Procedia-Social and Behavioral Sciences 1271-1278.

Zhou, Q., J. Hu, and S. Gao. 2010. Chemistry Teachers' Attitude Towards ICT in Xi'an. Procedia-Social and Behavioral Sciences 2(2): 4629-4637. 